\title{
Prognosis of segmentectomy in the treatment of stage IA non-small cell lung cancer (Review)
}

\author{
WENLIANG BAI and SHANQING LI \\ Department of Thoracic Surgery, Peking Union Medical College Hospital, Chinese Academy of \\ Medical Sciences and Peking Union Medical College, Beijing 100730, P.R. China
}

Received May 31, 2020; Accepted October 26, 2020

DOI: $10.3892 / 01.2020 .12335$

\begin{abstract}
With improvements in detection technology, increasing numbers of patients with non-small cell lung cancer (NSCLC) are being diagnosed at an early stage. In order to treat the illness with minimal invasion and preserve lung function to the greatest possible extent, there has been an increasing tendency towards treating early-stage NSCLC by segmentectomy. However, questions remain regarding whether patients may benefit from this procedure considering the surgical and oncological outcomes. Whether adequate margin distance and lymph node dissection may be achieved is one of the most important issues associated with this procedure. The present study reviews the prognosis of segmentectomy in the treatment of stage IA NSCLC.
\end{abstract}

\section{Contents}

1. Introduction

2. Surgical technique

3. Clinical outcomes

4. Oncological prognosis

5. Conclusion

\section{Introduction}

Lung cancer afflicts patients worldwide, accounting for $11.6 \%$ of all cancer cases and $18.4 \%$ of cancer-associated mortalities in 2018 (1). For patients with early-stage non-small cell lung cancer (NSCLC), lobectomy with lymph node dissection remains the standard treatment (2). Continuous optimization of surgical techniques, chemoradiotherapy,

Correspondence to: Dr Shanqing Li, Department of Thoracic Surgery, Peking Union Medical College Hospital, Chinese Academy of Medical Sciences and Peking Union Medical College, 1 Shuaifuyuan Road, Beijing 100730, P.R. China

E-mail: lishanqing_pumch@163.com

Key words: segmentectomy, lobectomy, non-small cell lung cancer gene-targeting treatment and immunotherapy has contributed to an increase in the 5-year survival rate to $19 \%$ (3). To preserve pulmonary function, segmentectomy has been suggested, but it has served primarily as a second choice for patients who cannot tolerate a lobectomy. Recently, NSCLC has been increasingly diagnosed at an early stage due to the widespread use of computed tomography $(4,5)$. A previous study has reported that $\sim 40 \%$ of patients who underwent surgical treatment were diagnosed at clinical stage IA NSCLC, indicating that less tissue could have been resected, preserving more lung function (6). Therefore, there has been a resurgence in interest in segmentectomy. Whether segmentectomy may be an advantageous tool for early-stage NSCLC remains controversial. The present study provides an overview of the prognosis of segmentectomy in treating stage IA NSCLC.

\section{Surgical technique}

The National Comprehensive Cancer Network (NCCN) recommends that, for patients who can tolerate a lobectomy, segmentectomy is feasible if the nodule is $\leq 2 \mathrm{~cm}$ in diameter and meets one of the following criteria: Adenocarcinoma in situ, ground-glass opacity $(\mathrm{GGO})>50 \%$ or doubling time $\geq 400$ days. Koike et al (7) compared the outcomes of 179 patients with clinical stage I NSCLC who underwent a segmentectomy. After a 4-year follow-up, solid tumor size was found to be an independent risk factor of recurrence. Additionally, $2.5 \%$ of patients whose tumor size was $<1.5 \mathrm{~cm}$ developed recurrence and $25 \%$ of patients with tumors $>1.5 \mathrm{~cm}$ developed recurrence.

Segmentectomy is more difficult for surgeons to perform and requires greater technical competence compared with lobectomy. It also requires accurate determination of the target segment. Inflating or deflating the segment during surgery are conventional methods and widely used (8). To achieve deflation, the lung is deflated on the side to be operated upon first; then, the target bronchus is tied or occluded before resuming ventilation. Multiple methods of inflating the segment have been proposed, including using a jet ventilator, incubating the target bronchus after resection, and using a slip knot for the target segment bronchus combined with bilateral ventilation $(9,10)$. Deflation of the segment does not require extra preparation and is easier to 
Table I. Studies comparing lobectomy and segmentectomy in functional consequences.

\begin{tabular}{|c|c|c|c|c|c|c|}
\hline First author, year & Procedure & Patients, $\mathrm{n}$ & $\begin{array}{c}\text { Mean predicted } \\
\text { pre-operative FEV1 }\end{array}$ & $\begin{array}{l}\text { Follow-up, } \\
\text { months }\end{array}$ & $\begin{array}{l}\text { Mean FEV1 } \\
\text { change, } \%\end{array}$ & (Refs.) \\
\hline \multirow[t]{2}{*}{ Takizawa et al, 1999} & Segmentectomy & 40 & $109 \%$ & 12 & -6.7 & \multirow[t]{2}{*}{$(16)$} \\
\hline & Lobectomy & 40 & $105 \%$ & 12 & -13.7 & \\
\hline \multirow[t]{2}{*}{ Keenan et al, 2004} & Segmentectomy & 54 & $55 \%$ & 12 & -5 & \multirow[t]{2}{*}{ (17) } \\
\hline & Lobectomy & 147 & $75 \%$ & 12 & -10 & \\
\hline \multirow[t]{2}{*}{ Okada et al, 2006} & Segmentectomy & 168 & 1.931 & 2 & -9.4 & \multirow[t]{2}{*}{ (18) } \\
\hline & Lobectomy & 168 & 2.321 & 2 & -16.8 & \\
\hline \multirow[t]{2}{*}{ Hwang et al, 2015} & Segmentectomy & 94 & $102 \%$ & 13 & -8.9 & \multirow[t]{2}{*}{ (19) } \\
\hline & Lobectomy & 94 & $101 \%$ & 18 & -11.0 & \\
\hline \multirow[t]{2}{*}{ Echavarria et al, 2016} & Segmentectomy & 43 & $76.4 \%$ & NA & -8.9 & \multirow[t]{2}{*}{$(20)$} \\
\hline & Lobectomy & 208 & $85.2 \%$ & NA & -20.6 & \\
\hline
\end{tabular}

NA, not available; FEV1, forced expiratory volume in 1 second.

perform intraoperatively. Inflation can reduce interference in the operative view, especially during thoracoscopy, and also avoids collateral ventilation occurrence.

Other methods used in identifying intersegmental planes include intravenous or intrabronchial indocyanine green injection (11), localization method (e.g., hookwire), virtual-assisted lung mapping by bronchoscopic multi-spot dye-marking, and 3D imaging $(12,13)$. These are less commonly used.

One of the biggest concerns is whether an adequate surgical margin can be obtained. Takahashi et al (14) studied the prognosis of patients with clinical stage I NSCLC treated by sublobar resection and showed that in patients who experienced recurrence, the margin distance to tumor size ratio was $<1$. This may be a predictive factor. Patients whose margin distance to tumor size was $\leq 1$ exhibited a poor 3 -year survival rate of $59.7 \%$. Although segmentectomy is an attractive method for early-stage NSCLC, it may be a risky choice if the margin distance or the margin distance to tumor size ratio is not ideal. Surgical standards must be established for its clinical use.

Since there is no accepted ideal regarding the size of the surgical margin needed to prevent relapse, it has come to be widely accepted that $15 \mathrm{~mm}$ in a deflated lung or $20 \mathrm{~mm}$ in an inflated lung is sufficient (15). The NCCN also indicates that a parenchymal resection margin of $\geq 2 \mathrm{~cm}$ or $\geq$ the size of the nodule should be obtained.

\section{Clinical outcomes}

There have been doubts regarding the safety and availability of segmentectomy since it involves complex anatomical resection, segment localization and intersegment identification (8).

In theory, segmentectomy could preserve more pulmonary tissue and promote the recovery of pulmonary function. Studies have shown that the long-term reduction in lung function induced by segmentectomy is less pronounced than that for lobectomy. The results are summarized in Table I (16-20). Certain researchers have reported that segmentectomy can offer patients a higher tolerance to resection in secondary cancer cases $(21,22)$. Compensatory adaptation of the remaining pulmonary tissue may be one of the reasons for this (23). Ideal anatomical segmentectomy resection is not always possible, especially in video-assisted thoracoscopic surgery (VATS). Segmentectomy could cause a more intense inflammatory state during an acute inflammatory response, whereby local extra surgical stress caused by damage may serve a large role (24).

A number of studies have shown that differences in the short-term clinical outcomes for stage I NSCLC between segmentectomy and lobectomy are insignificant. These outcomes include operation time, bleeding during surgery, duration of postoperative stay and air leakage. The results are summarized in Table II $(20,25-28)$. The duration of hospital stay following surgery is significantly shorter in some patients with VATS segmentectomy. For patients who can tolerate a lobectomy, anatomical segmentectomy resection is associated with faster postoperative recovery (29). This might be because patients who undergo VATS segmentectomy can achieve lung recruitment faster, allowing a shorter recovery before lung function returns to optimal levels (30). Ueda et al (31) found that patients who underwent segmentectomy were less susceptible to atrial fibrillation than lobectomy.

\section{Oncological prognosis}

Recurrence and survival. Although segmentectomy could preserve more pulmonary parenchyma than lobectomy, it remains unclear whether the remaining tissue could cause long-term harm to the oncological prognosis, considering the potential risk of an inadequate margin and lymph node dissection (32).

One study collected data from patients with T1bNOM0 NSCLC who underwent segmentectomy or lobectomy (33). The 5-year survival rates for patients who underwent a segmentectomy or lobectomy were 87.1 and $>87.7 \%$, respectively. Wen et al (34) retrospectively reviewed 1,018 patients with clinical N0 invasive lung adenocarcinoma of $>2 \mathrm{~cm}$ who underwent a segmentectomy or lobectomy. After an average 


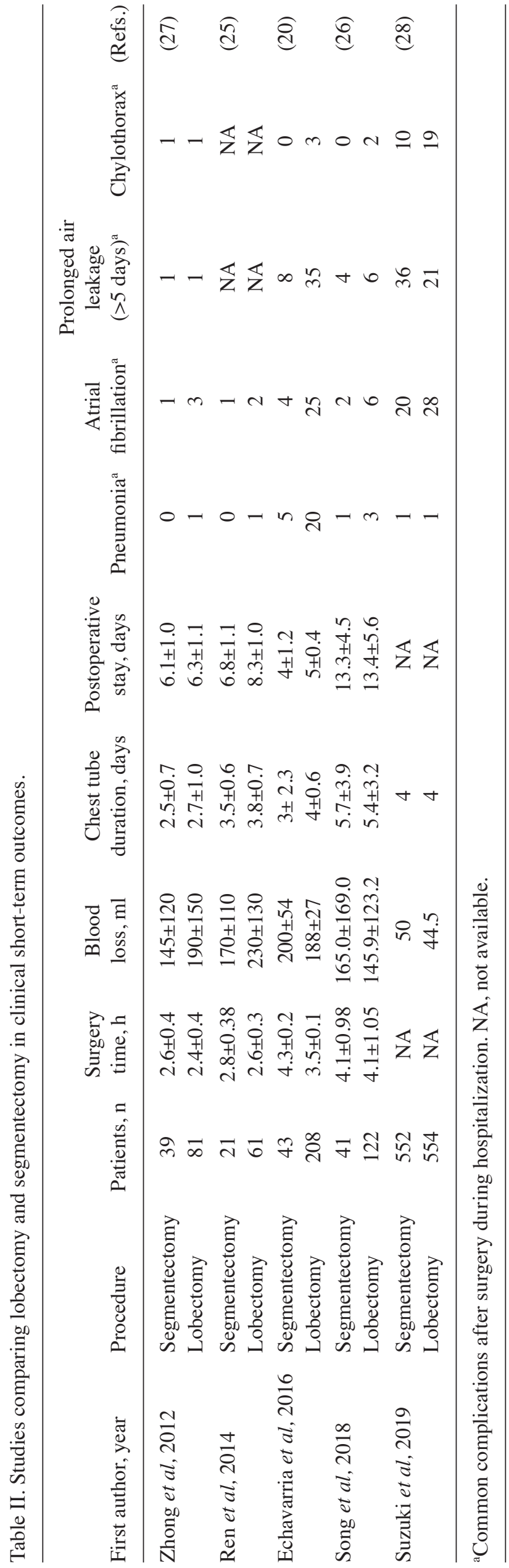

follow-up of 42.5 months, there was no significant difference in overall survival or recurrence-free survival between segmentectomy and lobectomy ( $\mathrm{P}=0.70$ and $\mathrm{P}=0.40$, respectively). Another study on stage IA and IB NSCLC showed similar results, with an overall recurrence rate of $17.6 \%$ following a segmentectomy and $16.7 \%$ following a lobectomy (35). Most recurrences were seen in patients with stage IB NSCLC. There was no significant difference in recurrence-free or overall survival between segmentectomy and lobectomy.

Previous reports have demonstrated that preserved lung parenchyma does not improve prognosis or increase the risk of recurrence $(18,36)$. Chan et al (37) compared surgical and oncological outcomes between segmentectomy and lobectomy in 369 patients with clinical T1cN0M0 NSCLC. The results showed no significant differences in short-term outcomes after surgery. Furthermore, no statistically significant difference was found in overall survival (hazard ratio (HR), 1.034; $\mathrm{P}=0.764)$, recurrence-free survival $(\mathrm{HR}, 1.168 ; \mathrm{P}=0.1391)$ or time to recurrence (HR, 1.053; $\mathrm{P}=0.7462)$. Numerous studies on early-stage NSCLC showed segmentectomy is not inferior to lobectomy for oncology prognosis. The results are summarized in Table III $(19,27,38-40)$. It has still not been confirmed whether segmentectomy is similar to the lobectomy with regards to outcomes since no recent studies have covered a follow-up period of $>5$ years. Long-term comparisons on prognosis are required to further understand these two methods.

Lymph nodes. The goal of segmentectomy for stage IA NSCLC is to achieve curative treatment, so adequate lymph node dissection becomes essential to ensuring that no metastatic lymph nodes are overlooked. As greater numbers of dissected lymph nodes are associated with later pathology stages $(41,42)$, one of the most important issues is whether the removal of enough lymph nodes can be guaranteed during a segmentectomy to prevent tumor under staging.

During the preoperative assessment for clinical staging, positron emission tomography (PET)/computed tomography (CT) is recommended since it provides a clearer distinction between hilar and mediastinal signals (43), but the risk of false-negative lymph nodes in PET/CT-normal patients remains (44).

Sun et al (45) assessed 200 patients with clinical T1N0M0 lung adenocarcinoma. For patients with pure GGN, maximum standard unit value (SUVmax) $<2.5$ or maximum tumor diameter $\leq 1 \mathrm{~cm}$, there is a low probability of segmental lymph node metastasis. Lutfi et al (46) showed that in patients with clinical stage IA NSCLC, the risk factors of pathologically-positive N1/2 lymph nodes after segmentectomy were tumor size and the number of lymph nodes sampled. Another study analyzed the N2 lymph node pathology of 224 patients with clinical stage I NSCLC who underwent a mediastinoscopy or surgery, which showed that $6.5 \%$ of clinical $\mathrm{T} 1$ patients and $8.7 \%$ of clinical T2 patients had positive N2 lymph nodes (47). The risk factors included large primary tumor size $(4.8 \%$ if $\leq 2 \mathrm{~cm}$, $6.5 \%$ if $2.1-6 \mathrm{~cm}$ and $57.1 \%$ if $\geq 6 \mathrm{~cm}$ ) and primary tumor SUVmax (1.9\% if $\leq 4$ and $10.5 \%$ if $>4)$. Gao et al (48) also found that in patients with clinical stage I NSCLC, 7\% were $\mathrm{N} 2$ pathological-positive. However, for patients with peripheral ground-glass or semisolid tumors, the N2 pathological-positive rate was $<2 \%$. 
Table III. Studies comparing lobectomy and segmentectomy in oncology prognosis.

\begin{tabular}{|c|c|c|c|c|c|c|}
\hline First author, year & Procedure & Clinical stage & Patients $n$ & Disease-free survival, $\%$ & Overall survival, $\%$ & (Refs.) \\
\hline Zhong et al, 2012 & $\begin{array}{l}\text { Segmentectomy } \\
\text { Lobectomy }\end{array}$ & IA & $\begin{array}{l}39 \\
81\end{array}$ & $\begin{array}{l}59.4^{\mathrm{a}} \\
64.2^{\mathrm{a}}\end{array}$ & $\begin{array}{l}79.9^{\mathrm{a}} \\
81.0^{\mathrm{a}}\end{array}$ & $(27)$ \\
\hline Yamashita et al, 2012 & $\begin{array}{l}\text { Segmentectomy } \\
\text { Lobectomy }\end{array}$ & IA & $\begin{array}{r}90 \\
124\end{array}$ & $\begin{array}{l}81.0^{\mathrm{a}} \\
89.0^{\mathrm{a}}\end{array}$ & $\begin{array}{l}75.0^{\mathrm{a}} \\
84.0^{\mathrm{a}}\end{array}$ & $(40)$ \\
\hline Hwang et al, 2014 & $\begin{array}{l}\text { Segmentectomy } \\
\text { Lobectomy }\end{array}$ & IA, IB & $\begin{array}{l}94 \\
94\end{array}$ & $\begin{array}{l}87.0^{\mathrm{b}} \\
94.0^{\mathrm{b}}\end{array}$ & $\begin{array}{l}94.0^{\mathrm{b}} \\
96.0^{\mathrm{b}}\end{array}$ & (19) \\
\hline Landreneau et al, 2014 & $\begin{array}{l}\text { Segmentectomy } \\
\text { Lobectomy }\end{array}$ & IA, IB & $\begin{array}{l}312 \\
312\end{array}$ & $\begin{array}{l}70.0^{\mathrm{a}} \\
54.0^{\mathrm{a}}\end{array}$ & $\begin{array}{l}71.0^{\mathrm{a}} \\
60.0^{\mathrm{a}}\end{array}$ & (38) \\
\hline Tsubokawa et al, 2018 & $\begin{array}{l}\text { Segmentectomy } \\
\text { lobectomy }\end{array}$ & IA, IB & $\begin{array}{l}52 \\
44\end{array}$ & $\begin{array}{l}84.1^{b} \\
82.2^{b}\end{array}$ & $\begin{array}{l}94.2^{\mathrm{b}} \\
92.0^{\mathrm{b}}\end{array}$ & (39) \\
\hline
\end{tabular}

${ }^{\mathrm{a}}$ Median follow up of 5 years. ${ }^{\mathrm{b}}$ Median follow up of 3 years.

One study showed that, compared with mediastinal lymph node dissection, mediastinal lymph node sampling has similar effects on survival in patients with early-stage N0 or N1 (less than hilar) NSCLC (49). Another study (50) showed data from 8,755 patients with clinical T1N0M0 NSCLC who experienced pathological N1/N2 metastasis after segmentectomy or lobectomy and completed adjuvant chemotherapy. Similar median survival times and 5-year overall survival rates were observed between segmentectomy and lobectomy for N1 metastasis (58.8 vs. 63.6 months, $49.7 \%$ vs. $52.4 \%, \mathrm{P}=0.11$ ) and $\mathrm{N} 2$ metastasis (55.6 vs. 50.4 months, $48.6 \%$ vs. $43.5 \%, \mathrm{P}=0.51$ ), indicating that a complete lobectomy may not be necessary for patients undergoing segmentectomy for cT1N0M0 NSCLC whereby no pathological N1/N2 metastasis is suspected.

These studies imply that, for clinical stage IA NSCLC, appropriate N1 and N2 lymph node sampling should be sufficient, and that invasive mediastinal lymph node dissection may not be necessary. The NCCN also suggests no need for invasive mediastinal staging in patients with peripheral stage IA (51). According to the European Society of Thoracic Surgeons guidelines, at least six nodes should be resected to secure appropriate pathological classification (52). However, for large tumors with high SUVmax or solid character, lymph node dissection should be considered first.

There is consensus that radical tumor resection, as the principle treatment, should always be considered first. The quality of life of the patient and the chance of tolerating a second resection, especially for patients with suspicious multiple primary lung cancer, should also be weighed. Surgeons should try to preserve as much normal pulmonary parenchyma as possible to ensure that these patients can tolerate a second resection on the same side.

\section{Conclusion}

For patients with stage IA NSCLC, segmentectomy is a safe choice and has been widely accepted, showing similar outcomes to lobectomy regarding short-term complications and prognosis of oncology. Although the complexity of a segmentectomy cannot be ignored, it is safe if performed by experienced surgeons. The essential part of segmentectomy is securing surgical margins and the dissection of enough lymph nodes. Since the majority of studies focused on a follow-up of $<5$ years, it is necessary to compare long-term prognosis. Comparisons of segmentectomy and other treatments that can be offered to patients with stage I lung cancer, such as stereotactic ablative body radiotherapy and radiofrequency ablation, could be performed for further indication.

\section{Acknowledgements}

Not applicable.

Funding

No funding was received.

\section{Availability of data and materials}

Not applicable.

\section{Authors' contributions}

WB wrote the manuscript. SL revised the manuscript critically for important intellectual content. Both authors read and approved the final manuscript.

\section{Ethics approval and consent to participate}

Not applicable.

\section{Patient consent for publication}

Not applicable.

\section{Competing interests}

The authors declare that they have no competing interests. 


\section{References}

1. Bray F, Ferlay J, Soerjomataram I, Siegel RL, Torre LA and Jemal A: Global cancer statistics 2018: GLOBOCAN estimates of incidence and mortality worldwide for 36 cancers in 185 countries. CA Cancer J Clin 68: 394-424, 2018.

2. Ginsberg RJ and Rubinstein LV: Randomized trial of lobectomy versus limited resection for T1 N0 non-small cell lung cancer. Lung Cancer Study Group. Ann Thorac Surg 60: 615-623, 1995.

3. Siegel RL, Miller KD and Jemal A: Cancer statistics, 2020. CA Cancer J Clin 70: 7-30, 2020.

4. Tammemagi MC and Lam S: Screening for lung cancer using low dose computed tomography. BMJ 348: g2253, 2014.

5. National Lung Screening Trial Research Team; Aberle DR, Adams AM, Berg CD, Black WC, Clapp JD, Fagerstrom RM, Gareen IF, Gatsonis C, Marcus PM and Sicks JD: Reduced lung-cancer mortality with low-dose computed tomographic screening. N Engl J Med 365: 395-409, 2011.

6. Goya T, Asamura H, Yoshimura H, Kato H, Shimokata K, Tsuchiya R, Sohara Y, Miya T and Miyaoka E; Japanese Joint Committee of Lung Cancer Registry: Prognosis of 6644 resected non-small cell lung cancers in Japan: A Japanese lung cancer registry study. Lung Cancer 50: 227-234, 2005.

7. Koike T, Nakamura A, Shimizu Y, Goto T, Sato S, Toyabe SI and Tsuchida M: Characteristics and risk factors of recurrence in clinical stage I non-small cell lung cancer patients undergoing anatomic segmentectomy. Gen Thorac Cardiovasc Surg 68: 1011-1017, 2020.

8. Sato M, Murayama T and Nakajima J: Concepts and techniques: How to determine and identify the appropriate target segment in anatomical pulmonary segmentectomy? J Thorac Dis 11 : 972-986, 2019.

9. Okada M, Mimura T, Ikegaki J, Katoh $\mathrm{H}$, Itoh $\mathrm{H}$ and Tsubota N: A novel video-assisted anatomic segmentectomy technique: Selective segmental inflation via bronchofiberoptic jet followed by cautery cutting. J Thorac Cardiovasc Surg 133: 753-758, 2007.

10. Endoh M, Oizumi H, Kato H, Suzuki J, Watarai H, Hamada A, Suzuki K, Nakahashi K and Sadahiro M: Determination of the intersegmental plane using the slip-knot method. J Thorac Dis 10 (Suppl 10): S1222-S1228, 2018.

11. Misaki N, Chang SS, Igai H, Tarumi S, Gotoh M and Yokomise H New clinically applicable method for visualizing adjacent lung segments using an infrared thoracoscopy system. J Thorac Cardiovasc Surg 140: 752-756, 2010.

12. Abdelsattar ZM and Blackmon SH: Using novel technology to augment complex video-assisted thoracoscopic single basilar segmentectomy. J Thorac Dis 10 (Suppl 10): S1168-S1178, 2018.

13. Yang SM, Lin CK, Chen LW, Chen YC, Huang HC, Ko HJ, Chen CM and Sato M: Combined virtual-assisted lung mapping (VAL-MAP) with CT-guided localization in thoracoscopic pulmonary segmentectomy. Asian J Surg 42: 488-494, 2019.

14. Takahashi N, Sawabata N, Kawamura M, Ohtsuka T, Horio H, Sakaguchi H, Nakayama M, Yoshiya K, Chida M and Hoshi E; All the co-authors are members of Kan-Etsu Lung Cancer Study Group (KLSG): Optimal sublobar resection for c-stage I non-small cell lung cancer: Significance of margin distance to tumor size ratio and margin cytology (Supplementary analysis of KLSG-0801): Complete republication. Gen Thorac Cardiovasc Surg 67: 690-696, 2019.

15. Fell SC and Kirby TJ: Limited pulmonary resection in thoracic Surgery (2nd ed). New York, Churchill Livingstone 2020: 1002-1004, 2002.

16. Takizawa $\mathrm{T}$, Haga $\mathrm{M}$, Yagi $\mathrm{N}$, Terashima $\mathrm{M}$, Uehara $\mathrm{H}$, Yokoyama A and Kurita Y: Pulmonary function after segmentectomy for small peripheral carcinoma of the lung. J Thorac Cardiovasc Surg 118: 536-541, 1999

17. Keenan RJ, Landreneau RJ, Maley RH Jr, Singh D, Macherey R, Bartley $\mathrm{S}$ and Santucci T: Segmental resection spares pulmonary function in patients with stage I lung cancer. Ann Thorac Surg 78: 228-233, 2004

18. Okada M, Koike T, Higashiyama M, Yamato Y, Kodama K and Tsubota N: Radical sublobar resection for small-sized non-small cell lung cancer: A multicenter study. J Thorac Cardiovasc Surg 132: 769-775, 2006.

19. Hwang Y, Kang CH, Kim HS, Jeon JH, Park IK and Kim YT: Comparison of thoracoscopic segmentectomy and thoracoscopic lobectomy on the patients with non-small cell lung cancer: A propensity score matching study. Eur J Cardiothorac Surg 48: 273-278, 2015.
20. Echavarria MF, Cheng AM, Velez-Cubian FO, Ng EP, Moodie CC, Garrett JR, Fontaine JP, Robinson LA and Toloza EM: Comparison of pulmonary function tests and perioperative outcomes after robotic-assisted pulmonary lobectomy vs segmentectomy. Am J Surg 212: 1175-1182, 2016.

21. Harada H, Okada M, Sakamoto T, Matsuoka H and Tsubota N: Functional advantage after radical segmentectomy versus lobectomy for lung cancer. Ann Thorac Surg 80: 2041-2045, 2005.

22. Charloux A and Quoix E: Lung segmentectomy: Does it offer a real functional benefit over lobectomy? Eur Respir Rev 26: $170079,2017$.

23. Mizobuchi T, Wada H, Sakairi Y, Suzuki H, Nakajima T, Tagawa T, Iwata T, Motoori K, Yoshida S and Yoshino I: Spirometric and radiological evaluation of the remnant lung long after major pulmonary resection: Can compensatory phenomena be recognized in clinical cases? Surg Today 44: 1735-1743, 2014.

24. Ishikawa $Y$, Kojima F, Ishii T, Yoshiyasu N, Ohde S and Bando T: Early postoperative inflammatory response by procedure types: Stapler-based segmentectomy versus lobectomy. Gen Thorac Cardiovasc Surg 68: 280-286, 2020.

25. Ren M, Meng Q, Zhou W, Kong F, Yang B, Yuan J, Wu D, Zhang J, Li Q, Lin Y, et al: Comparison of short-term effect of thoracoscopic segmentectomy and thoracoscopic lobectomy for the solitary pulmonary nodule and early-stage lung cancer. Onco Targets Ther 7: 1343-1347, 2014.

26. Song CY, Sakai T, Kimura D, Tsushima T and Fukuda I: Comparison of perioperative and oncological outcomes between video-assisted segmentectomy and lobectomy for patients with clinical stage IA non-small cell lung cancer: A propensity score matching study. J Thorac Dis 10: 4891-4901, 2018.

27. Zhong C, Fang W, Mao T, Yao F, Chen W and Hu D: Comparison of thoracoscopic segmentectomy and thoracoscopic lobectomy for small-sized stage IA lung cancer. Ann Thorac Surg 94: 362-367, 2012.

28. Suzuki K, Saji H, Aokage K, Watanabe S, Okada M, Mizusawa J, Nakajima R, Tsuboi M, Nakamura S, Nakamura K, et al: Comparison of pulmonary segmentectomy and lobectomy: Safety results of a randomized trial. J Thorac Cardiovasc Surg 158: 895-907, 2019.

29. Zeng W, Zhang W, Zhang J, You G, Mao Y, Xu J, Yu D, Peng J and Wei Y: Systematic review and meta-analysis of video-assisted thoracoscopic surgery segmentectomy versus lobectomy for stage I non-small cell lung cancer. World J Surg Oncol 18: 44, 2020.

30. Yoshimoto K, Nomori H, Mori T, Kobayashi H, Ohba Y, Shibata H, Tashiro K, Shiraishi S and Kobayashi T: Quantification of the impact of segmentectomy on pulmonary function by perfusion single-photon-emission computed tomography and multidetector computed tomography. J Thorac Cardiovasc Surg 137: 1200-1205, 2009.

31. Ueda T, Suzuki K, Matsunaga T, Takamochi K and Oh S: Postoperative atrial fibrillation is less frequent in pulmonary segmentectomy compared with lobectomy. Gen Thorac Cardiovasc Surg 66: 95-100, 2018.

32. Sienel W, Stremmel C, Kirschbaum A, Hinterberger L, Stoelben E, Hasse J and Passlick B: Frequency of local recurrence following segmentectomy of stage IA non-small cell lung cancer is influenced by segment localisation and width of resection margins-implications for patient selection for segmentectomy. Eur J Cardiothorac Surg 31: 522-528, 2007.

33. Okada M, Sakamoto T, Nishio W, Uchino K and Tsubota N: Characteristics and prognosis of patients after resection of nonsmall cell lung carcinoma measuring $2 \mathrm{~cm}$ or less in greatest dimension. Cancer 98: 535-541, 2003.

34. Wen Z, Zhao Y, Fu F, Hu H, Sun Y, Zhang Y and Chen H: Comparison of outcomes following segmentectomy or lobectomy for patients with clinical N0 invasive lung adenocarcinoma of $2 \mathrm{~cm}$ or less in diameter. J Cancer Res Clin Oncol 146: 1603-1613, 2020.

35. Schuchert MJ, Pettiford BL, Keeley S, D'Amato TA, Kilic A, Close J, Pennathur A, Santos R, Fernando HC, Landreneau JR, et al: Anatomic segmentectomy in the treatment of stage I non-small cell lung cancer. Ann Thorac Surg 84: 926-933, 2007.

36. Martin-Ucar AE, Nakas A, Pilling JE, West KJ and Waller DA: A case-matched study of anatomical segmentectomy versus lobectomy for stage I lung cancer in high-risk patients. Eur J Cardiothorac Surg 27: 675-679, 2005.

37. Chan EG, Chan PG, Mazur SN, Normolle DP, Luketich JD, Landreneau RJ and Schuchert MJ: Outcomes with segmentectomy versus lobectomy in patients with clinical T1cN0M0 non-small cell lung cancer. J Thorac Cardiovasc Surg: Mar 23, 2020 doi: 10.1016/j.jtcvs.2020.03.041 (Epub ahead of print). 
38. Landreneau RJ, Normolle DP, Christie NA, Awais O, Wizorek JJ, Abbas G, Pennathur A, Shende M, Weksler B, Luketich JD and Schuchert MJ: Recurrence and survival outcomes after anatomic segmentectomy versus lobectomy for clinical stage I non-small-cell lung cancer: A propensity-matched analysis. J Clin Oncol 32: 2449-2455, 2014.

39. Tsubokawa N, Tsutani Y, Miyata Y, Handa Y, Misumi K, Hanakiet $\mathrm{H}$, Hida E and Okada M: Segmentectomy versus lobectomy for radiologically pure solid clinical T1a-bNOM0 lung cancer. World J Surg 42: 2493-2501, 2018.

40. Yamashita S, Tokuishi K, Anami K, Morgan T, Miyazaki M, Chujo M, Yamamoto S and Kawahara K: Thoracoscopic segmentectomy for T1 classification of non-small cell lung cancer: A single center experience. Eur J Cardiothorac Surg 42: $83-88,2012$.

41. Krantz SB, Lutfi W, Kuchta K, Wang CH, Kim KW and Howington JA: Improved lymph node staging in early-stage lung cancer in the national cancer database. Ann Thorac Surg 104: $1805-1814,2017$.

42. Ohtsuka T, Kamiyama I, Asakura K and Kohno M: Thirty-day outcomes after lobectomy or segmentectomy for lung cancer surgery. Asian Cardiovasc Thorac Ann 23: 828-831, 2015.

43. Silvestri GA, Gonzalez AV, Jantz MA, Margolis ML, Gould MK, Tanoue LT, Harris LJ and Detterbeck FC: Methods for staging non-small cell lung cancer: Diagnosis and management of lung cancer, 3rd ed: American College of Chest Physicians evidence-based clinical practice guidelines. Chest 143 (5 Suppl): e211S-e250S, 2013.

44. Silvestri GA, Gould MK, Margolis ML, Tanoue LT, McCrory D, Toloza E and Detterbeck F; American College of Chest Physicians: Noninvasive staging of non-small cell lung cancer: ACCP evidenced-based clinical practice guidelines (2nd edition) Chest 132 (Suppl 3): 178S-201S, 2007.

45. Sun G, Sun Y, Zou Z and Xu S: Analysis of segmental lymph node metastasis and clinical features in cT1N0M0 lung adenocarcinoma. Biomed Res Int 2020: 2842604, 2020.
46. Lutfi W, Schuchert MJ, Dhupar R, Ekeke C, Sarkaria IS, Christie NA, Luketich JD and Okusanya OT: Node-positive Segmentectomy for Non-small-cell lung cancer: Risk factors and outcomes. Clin Lung Cancer 20: e463-e469, 2019.

47. Lee PC, Port JL, Korst RJ, Liss Y, Meherally DN and Altorki NK: Risk factors for occult mediastinal metastases in clinical stage I non-small cell lung cancer. Ann Thorac Surg 84: 177-181, 2007.

48. Gao SJ, Kim AW, Puchalski JT, Bramley K, Detterbeck FC, Boffa DJ and Decker RH: Indications for invasive mediastinal staging in patients with early non-small cell lung cancer staged with PET-CT. Lung Cancer 109: 36-41, 2017.

49. Darling GE, Allen MS, Decker PA, Ballman K, Malthaner RA, Inculet RI, Jones DR, McKenna RJ, Landreneau RJ, Rusch VW and Putnam JB Jr: Randomized trial of mediastinal lymph node sampling versus complete lymphadenectomy during pulmonary resection in the patient with N0 or N1 (less than hilar) non-small cell carcinoma: Results of the American College of Surgery Oncology Group Z0030 Trial. J Thorac Cardiovasc Surg 141: 662-670, 2011.

50. Razi SS, Nguyen D and Villamizar N: Lobectomy does not confer survival advantage over segmentectomy for non-small cell lung cancer with unsuspected nodal disease. J Thorac Cardiovasc Surg 159: 2469-2483.e4, 2020.

51. National Comprehensive Cancer Network: NCCN Clinical Practice Guidelines in Oncology. Non-Small Cell Lung Cancer guidelines. v3, 2019.

52. Lardinois D, De Leyn P, Van Schil P, Porta RR, Waller D, Passlick B, Zielinski M, Lerut T and Weder W: ESTS guidelines for intraoperative lymph node staging in non-small cell lung cancer. Eur J Cardiothorac Surg 30: 787-792, 2006.

This work is licensed under a Creative Commons Attribution-NonCommercial-NoDerivatives 4.0 International (CC BY-NC-ND 4.0) License. 